\title{
ПРОБЛЕМА МОРАЛЬНОГО ВИХОВАННЯ ДІТЕЙ ДОШКІЛЬНОГО ВІКУ: ТЕОРЕТИЧНИЙ АСПЕКТ
}

\author{
Княжева I. А. Проблема морального виховання дітей дошкільного віку: \\ теоретичний аспект. \\ У статті проаналізовано теоретичні передумови проблеми морального виховання дітей \\ дошкільного віку, виокремлено основні напрями наукових розвідок щодо морального виховання \\ дітей дошкільного віку, схарактеризовано особливості нормативного й особистісно \\ зорієнтованого підходу в роботі вихователів до організації педагогічного процесу сучасних \\ дошкільних навчальних закладів.
}

Ключові слова: моральне виховання, діти дошкільного віку, нормативний підхід, особистісно зорієнтований підхід, вихователі, дошкільні навчальні заклади.

Княжева И. А. Проблема нравственного воспитания детей дошкольного возраста: теоретический аспект.

В статье проанализированы теоретические предпосылки проблемы нравственного воспитания детей дошкольного возраста, выделены основные направления научных исследований по нравственному воспитанию детей дошкольного возраста, определены особенности нормативного и личностно ориентированного подхода в работе воспитателей к организации педагогического процесса современных дошкольных образовательных учреждений.

Ключевые слова: нравственное воспитание, дети дошкольного возраста, нормативный подход, личностно-ориентированный подход, воспитатели, дошкольные образовательные учреждения.

Knyazheva I. A. Problem of moral education of preschool children: theoretical aspect.

In the article theoretical bases of the problem of moral education of preschool children were analysed, basic directions of scientific researches on issue of moral education of under-fives were selected, the features of normative and person centered approaches in the work of educators of preschool educational institutions were described.

Key words: moral education, preschool age children, normative approach, personal based approach, educators, preschool educational institutions.

Зміни, що відбуваються в нашому суспільстві, викликали неоднозначні процеси. 3 одного боку, розбудовується система соціального і правового захисту людини, якої особливо потребують найбільш вразливі члени суспільства: інваліди, люди похилого віку, діти-сиріти. Виникають благодійні товариства, фонди милосердя і здоров’я, відроджується корпус сестер милосердя, покоївок, сімейних лікарів, педагогів, у тому числі для інклюзивної освіти, i система їхньої спеціальної підготовки. Усе більше усвідомлюється миротворча місія церкви, що накопичила тисячолітній досвід морального виховання, їі роль у духовному очищенні суспільства.

3 іншого боку, поряд із ніжними добрими паростками, реальністю є зростання жорстокості і правопорушень, девальвація духовних цінностей. Ці дві протилежні тенденції осмислюються й досліджуються. Багато науковців бачать вихід із духовної кризи суспільства 
не лише у прийнятті безпосередніх кроків щодо припинення зла і насильства. Шлях до духовного оздоровлення пролягає через підвищення культурного рівня, відродження духовних цінностей, демократизацію й оновлення системи освіти, де пріоритетним стають гуманістичні тенденції, моральне виховання дітей і юнацтва, саморозкриття, творче самовираження особистості. Отже, проблема морального виховання нині $є$ важливою й актуальною.

Аналізуючи дослідження в галузі морального виховання дітей дошкільного віку, можна умовно виокремити чотири їх напрями:

1) моральна поведінка, як така, що орієнтується на норми моралі навіть тоді, коли їх порушення матиме певну користь і дитина переконана в тому, що покарання за їх порушення не буде (В. Абраменкова, Л. Артемова, Р. Буре, Р. Іванкова, Л. Кадирова, О. Кисельова, С. Кулачковська, Н. Михайленко, В. Павленчик, Т. Поніманська, Т. Фасолько та ін.);

2) морально цінні і суспільно схвалені гуманістичні й альтруїстичні почуття, якості, ставлення (Л. Абрамян, О. Бутенко, О. Кононко, О. Косарєва, Г. Кошелєва, Е. Кульчицька, Г. Лаврентєва, І. Лапченко, В. Маршицька, Ю. Приходько, Н. Славіна, Л. Стрєлкова, Є. Субботський та ін.);

3) моральні знання, уявлення, судження, переконання (3. Борисова, А. Виноградова, Л. Князєва, В. Котирло, Т. Маркова, . Неверович, Л. Островська, Т. Понаморенко, С. Якобсон та ін.);

4) моральні переживання (Р. Жуковська, Л.-Ц. Майденкене, В. Мухіна, В. Пушміна, Н. Тимошенко та ін.).

Поданий розподіл досліджень за чотирма напрямами є досить умовним і не охоплює всього розмаїття сучасних досліджень, тематика яких постійно розширюється і поглиблюється.

Метою статті є виокремлення теоретичних передумов розв'язання проблеми морального виховання дітей дошкільного віку.

Людина розвивається, формується, стає особистістю під впливом і в оточенні інших людей. Дитина засвоює соціальні впливи через різноманітні групи, членом якої вона $є$. Першою і за часом, і за значенням такою групою $є$ сім'я. Члени родині - це одночасно i представники покоління, і нації, і держави. Сім’я створює умови життя, які значною мірою визначають увесь подальший хід розвитку особистості. Тисячолітнє багатство людської культури засвоюється дитиною завдяки активній взаємодії із соціальним довкіллям. I суспільні вимоги стають особистими лише в результаті спільної діяльності і спілкування 3 тими, хто отчує, серед яких на першому місті, звичайно, найрідніші люди - батьки.

Духовна спадщина минулого зберігається і передається не лише у вигляді пам'яток науки чи мистецтва, вона охоплює різноманітні форми соціального управління моральним розвитком людини. За довгий період розвитку суспільство створило різні форми соціальної регуляції поведінки індивіда. До них належать мораль, право, релігія, політика, звичаї, традиції, обряди. Кожна з цих форм своєрідно нагадує людині про ії приналежність до тієї чи тієї соціальної групи, необхідність ураховувати інтереси цієї спільноти. Цілісність групи залежить від визнання ï членами єдиних норм взаємодії, досягнення згоди, санкцій за їх порушення.

Мораль $є$ найбільш універсальним засобом соціальної регуляції поведінки людини. Мораль - це вимоги, які висуває суспільство поведінці людини, це ті загальнолюдські норми і правила поведінки, які визначають обов’язки і ставлення людей один до одного і до суспільства в цілому. 
Моральність людини охоплює як їі внутрішній світ, як розуміння того, як і чому потрібно чинити, так і зовнішню сторону його вияву, що виражається в судженнях, учинках, поведінці. Поняття «моральність» і «моральний» використовуються для характеристики практичних взаємин між людьми, тих учинків і дій, які вони здійснюють.

Проблема морального виховання - це значною мірою проблема формування особистості дитини. Формування особистості в дошкільному дитинстві пов'язане 3 вихованням моральних якостей, творчих здібностей, розкриттям індивідуальності дитини. Процес формування особистості дитини - процес складний, тривалий, такий, що змінюється в своєму розвиткові i змісті. Він вимагає цілеспрямованого і систематичного виховного впливу.

Моральне виховання традиційно вважається одним із основних шляхів формування особистості. Моральне виховання - це цілеспрямована взаємодія дорослого і дитини з метою формування моральних почуттів і якостей, засвоєння моральних норм і правил, розвитку моральних мотивів і навичок поведінки [5, с. 98].

Моральний розвиток особистості, з одного боку, є процесом активного засвоєння моральних цінностей, якісних позитивних змін в особистості під упливом багатьох чинників (соціального довкілля, виховання, досвіду діяльності, самовиховання тощо), а з іншого,моральний розвиток може бути схарактеризований як досягнутий особистістю рівень моральної вихованості.

Моральне виховання зазвичай виокремлюється як особлива, відносно самостійна галузь педагогічної практики, що має власні цілі і засоби виховних впливів. Дійсно, дітей потрібно вчити тому, як поводитись у суспільстві, як ставитися до інших людей. Однак моральне виховання не зводиться до формального засвоєння дітьми норм етики, соціально схвалюваних прикладів поведінки. Його сутність- не в повчальних моралізуваннях, а у формуванні людських взаємин дошкільників з довколишніми.

Моральне виховання розпочинається 3 перших років і навіть днів життя дитини. Дитина рано вступає у спілкування з людьми, під впливом чого в неї виникають перші взаємини, симпатії, звички. П. Лесгафт справедливо стверджував, що характер людини розпочинає формуватися в перші роки їі життя. Дошкільне дитинство теоретично й експериментально визначено як період, найбільш сприятливий для розвитку особистості. Пластичність психіки (Л. Виготський, С. Рубінштейн), емоційна чутливість, що сприяє розвиткові моральних почуттів (О. Запорожець, В. Котирло, Г. Кошелєва, Е. Кульчицька та ін.), новоутворення у вигляді усвідомлених мотивів, здатні підкорити безпосередні бажання (О. Леонтьєв), поява внутрішніх етичних інстанцій (Д. Ельконін) роблять дошкільний вік сенситивним періодом для формування моральних основ особистості.

Розвиткові моральних основ особистості в дошкільному дитинстві сприяють також такі основні психологічні передумови:

- соціальна потреба дошкільників у спілкуванні;

- орієнтація на дорослого як джерело моральних взірців, на оцінку ровесників як на умову благоприємного положення серед них;

- інтерес до суспільних явищ, (у тому числі до моральних норм), що постійно розвивається;

- емоційно позитивне ставлення до моральних норм як регуляторів взаємин 3 оточуючими;

- здатність до усвідомленої супідрядності особистих прагнень суспільним 
мотивам [4].

Дитина впродовж дошкільного дитинства засвоює суспільний досвід, оволодіває моральними нормами. За даними психології (І. Бронніков, Л. Виготський, О. Запорожець, В. Мухіна, М. Поддьяков, Д. Ельконін та ін.) знання про мораль певною мірою керують дитячою поведінкою. Їх особливе значення визначається тим, що засвоєння дітьми етичних уявлень про добро і зло є джерелом внутрішніх регулятивних механізмів їхньої поведінки.

Л. Божович [2] стверджувала, що дитина засвоює з довкілля лише те, що відповідає її потребам. Вона довела взаємозв’язок моральних почуттів, моральної свідомості та моральної поведінки малят. Необхідною умовою переходу моральних норм із зовнішніх у внутрішні уважала включення дитини в життя колективу, оскільки в цьому випадку норми стають важливими для неї.

У дослідженнях Л. Артьомової, М. Буєвої. А. Ковальова, Я. Коломінського, Т. Репіної та ін. доведено, що спілкування 3 дорослими $€$ важливим шляхом набуття дитиною різноманітних знань, моральних норм, інтересів. Під упливом спілкування з дорослими під час різноманітних видів діяльності в дітей формуються уявлення про довкілля, моральні норми, а також певне ставлення до того, що пізнається, розуміння прекрасного і поганого у вчинках і поведінці людей, інакше кажучи, морально-етичні оцінки.

О. Леонтьєв підкреслював, що для того, щоб моральна вимога перетворилась із формальної на регулювальну, дитина повинна не тільки знати, а й усвідомлювати їі, вона має стати для дитини значущою. Це можливо, якщо ця вимога ввійде до структури центральних мотивів особистості, контексту ії провідної діяльності. Отже, моральний розвиток розглядається як такий, що має дві сторони: пізнавальну i мотиваційну, що не завжди збігаються.

Моральне виховання здійснюється у процесі засвоєння усталених норм і еталонів поведінки. Л. Виготський вважав основою побудови особистості перенесення у внутрішній план зовнішніх соціальних відносин. Саме так засвоєна дитиною норма перетворюється на мотив поведінки.

О. Кульчицька підкреслює, що моральне виховання розпочинається 3 розвитку в дитини гуманних почуттів як первинного переживання позитивного характеру. До такого роду первинних переживань, «зародків» більш складних за своєю структурою гуманних почуттів, вона віднесла жалість і співчуття. Н. Лисенко і Л. Ляміна уважають, що першою формою вияву соціальних почуттів дітей $\epsilon$ симпатія, що стає основою для розвитку гуманності.

А. Ковальов стверджував, що дійова турбота і співчуття до інших людей, що виявляються в дошкільному віці означають зародження морального почуття, без якого не можливо моральне виховання [3].

Моральні почуття не можуть виникнути шляхом природного визрівання. Їх розвиток залежить від методів і прийомів виховання, від умов, у яких живе дитина. За умови цілеспрямованого виховання вони розвиваються раніше, стають багатшими i різноманітнішими. Чим глибше дитина проникає в дійсність, тим більш диференційованими стають їі почуття. Саме тому стійкі й усвідомлені почуття базуються на знаннях, тобто наявний тісний зв’язок між почуттями і знаннями.

Механізм формування гуманних почуттів і якостей особистості передбачає здатність дитини до рефлексії, тобто можливості оцінювати себе 3 точки зору іншої людини, аналізувати свої дій, приймати рішення, ураховуючи при цьому можливу реакцію на них партнерів по спілкуванню, наслідки своїх учинків [7]. 
I. Дьоміна уважає, що розвиток моральних почуттів вимагає від дитини усвідомлення необхідності додержуватися правил суспільної поведінки, розуміти зміст вимог, що висуваються, уміння співвідносити ці вимоги і свою поведінку, а також вчинки інших людей.

На думку Е. Суботського [6], ефективна зміна реальної поведінки дитини неможлива лише шляхом доведення до іï свідомості соціально бажаних форм поведінки. Вона здійснюється завдяки зміні реальних взаємозв’язків дитини з людьми, які їі оточують, що зумовлює модифікацію змістових новоутворень дошкільника. Важливо при цьому виховувати внутрішні стимули моральної поведінки. Дитина має призвичаюватися поводитися не тільки згідно з вимогами і вказівками дорослих, але й відповідно до власних вимог до себе, основою яких є розуміння необхідності чинити так чи так. Керуючись знанням норм і правил поведінки, дитина привчається висувати ці вимоги до себе. У такий спосіб формуються внутрішні стимули поведінки. Такими внутрішніми стимулами моральної поведінки, як відомо, є потреби, почуття, переконання, ідеали, звички.

Соціально значущий виховний ефект $\epsilon$, як правило, результатом включення дошкільника в різноманітні види діяльності - гру, малювання, вирішення пізнавальних задач тощо, яким надається вільний самодіяльний характер. При цьому дітей стимулюють до співробітництва один 3 одним, обміну досвідом, відпрацюванню планів і способів досягнення результатів діяльності. Не «запрограмованість», а всебічне сприяння розвиткові індивідуальності дитини повинно лежати в основі діяльності педагога-вихователя.

Зовнішні вимоги до дитини мають обов’язково стати їі внутрішніми прагненнями стійкими мотивами поведінки, уможливити здійснення самоконтролю за власними вчинками і діями.

Виховання, що ігнорує внутрішні зміни у думках, почуттях, потребах і прагненнях дитини та зводиться лише до зовнішніх впливів і регламентацій, не є результативним. Воно призводить до формування негативних якостей особистості, тоді як правильно організоване виховання, у якому вимоги до дитини поєднуються з повагою до неї, сприяють до переходу особистості на більш високий рівень розвитку.

Із класичної педагогіки можна виокремити два важливих напрями, розвиток яких розглядається як ключ до розв'язання питання про виховання моральної особистості. Перший - моральність виражає інтереси суспільства і за певних умов може стати потребою особистості; другий - умовами і засобами формування особистості $\epsilon$ відносини морального характеру.

У теорії морального розвитку особистості, його генезису і специфіки на етапі дошкільного дитинства деякий час домінував нормативний підхід. Моральний розвиток дитини розглядавсь як процес засвоєння прийнятих у суспільстві моральних норм, що втілювались у вимогах і оцінках та визначали зміст моральний дій, їх мотивацію й усвідомлення. (О. Богданова, Л. Божович, Т. Маркова та ін.).

Нині продуктивним визнається особистісно зорієнтований, гуманний підхід. Загальні принципи такого підходу містяться у взаємній довірі, створенні мікроклімату поваги, коли педагог в усіх справах разом із вихованцями, коли спілкування необхідне, цікаве і дитині, i дорослому, а формальні навчально-дисциплінарні обставини переходять на другий план, а їх місце займає душа дитини, особистість, зі своїми інтересами та проблемами; у здійсненні активної, творчої ролі дітей дошкільного віку як суб'єктів, а не лише об'єктів педагогічного процесу.

Науково-теоретичні уявлення про особистісно зорієнтований підхід до виховання і навчання складалися впродовж багатьох століть. Значний вплив на становлення сучасної 
теорії і практики особистісно зорієнтованої освіти здійснили ідеї П. Блонського, К. Вентцеля, А. Духновича, Я. Коменського, Я. Корчака, М. Пірогова, Г. Сковороди, В. Сухомлинського, К. Ушинського та ін. Саме під впливом цих ідей проводилися дослідження Ю. Азарова, Ш. Амонашвілі, Г. Гаврилової, О. Кононко, Л. Стрєлкової, Е. Субботського та ін.

Вони та їхні однодумці підкреслюють необхідність альтруїстичного, довірчого, демократичного стилю спілкування на основі співробітництва дорослого з дитиною. Такий стиль $є$ зразком безкорисливої моральної поведінки, що формується в дошкільників. Він реалізується у стосунках з дітьми і фактично виступає як приваблива, емоційно забарвлена дієва норма. Такий підхід відповідає духу демократизації суспільства, він дозволяє вже в дошкільному дитинстві бачити в дитині не об’єкт, а суб'єкт виховних впливів, передбачає розуміння дитини як найвищої соціальної цінності, максимально повне розкриття ії особливостей, здібностей і прагнень, віру в можливості дитини, забезпечення гармонійних відносин між людьми, суспільством і природою [1].

Психологічний комфорт, безпека в педагогічному процесі створює в його учасників умови для більшої самореалізації, саморозкриття творчих можливостей. Практична реалізація цих принципів особистісно зорієнтованого підходу, перш за все, залежить від рівня професійно-педагогічної підготовки педагога, його особистих та професійних настанов, позиції щодо вихованців, використаних форм і методів організації виховного процесу дошкільного навчального закладу и, підкреслюється в дослідженнях Г. Бєленької, А. Богуш, Е. Карпової, К. Крутій, Н. Лисенко, Т. Поніманської та ін.

Особистісно зорієнтований підхід до дитини нині не лише декларується - він успішно втілюється у практиці роботи передових педагогів. Педагог-майстер бачить у дитині неповторну індивідуальність з розмаїттям якостей і особливостей та на цій основі розробляє стратегію виховання. Він звичайно розмежовує прагнення дитині до певних ступенів свободи, самостійності, незалежності, бере до уваги її потребу в тому, щоб реалізовувати бажання бути визнаним, самостверджуватись у спільноті ровесників. Звідси і пошук таких форм організації діяльності дітей, що уможливлюють створення найбільш широкого простору для вияву ними соціально значущої активності, забезпечують високу динамічність і гнучкість пошукової діяльності дитини, розкривають увесь потенціал пї творчих можливостей. Саме тому перспективу подальших наукових розвідок убачаємо в узагальненні, систематизації і розробленні ефективних технологій, що сприяють вирішенню проблем морального виховання дітей дошкільного віку.

\section{Література}

1. Амонашвили Ш. А. Размышления о гуманной педагогике / Ш. А. Амонашвили. [2-е изд.]. - Москва : Издат. Дом Шалвы Амонашвили, 2001. - 461 с. 2. Божович Л. И. Личность и ее формирование в детском возрасте / Л. И. Божович. - Санкт-Петербург : Питер, 2008. - 400 с. 3. Виховання дошкільника в праці/ [3. Н. Борисова, Г. В. Бєлєнька, М. А. Машовець та ін.]. - [2-е вид., стер.]. - Київ, 2002. - 112 с. 4. Кононко О. Л. Психологічні основи особистісного становлення дошкільника: (системний підхід)/ О. Л. Кононко. - Київ : Стилос, 2000. - 336 с. 5. Поніманська Т. І. Дошкільна педагогіка : [навч. посіб. для студ. вищ. навч. закл] / Т. І. Поніманська. - Київ : Академвидав, 2008. 456 с. 6. Субботский Е. В. Ребенок открывает мир / Е. В. Субботский. - Москва : Просвещение, 1991.-134 с. 7. Эмоциональное развитие дошкольника : [учеб. пособ.]/ А. Д. Кошелева, С. А. Козлова, О. А. Шаграева. - Москва : Академия, 2003. - 176 с. 